\title{
The Formation of Protoplasts and Quasi-spheroplasts in Normal and Chloramphenicol-pretreated Bacillus subtilis
}

\author{
By I. L. MILLER, R. M. ZSIGRAY AND O. E. LANDMAN \\ Department of Biology, Georgetown University, Washington, D.C. 20007, U.S.A.
}

(Accepted for publication I July 1967)

\begin{abstract}
SUMMARY
The lytic action of lysozyme upon Bacillus subtilis walls was studied by following the disappearance of bacillary-colony-forming units and the appearance of L-colony-forming-units. The rapidity of cell wall removal by lysozyme fluctuated markedly during growth in a chemically defined medium, presumably because subtle changes in the cell wall were constantly occurring. When lysozyme-sensitive bacilli were grown with chloramphenicol $10 \mu \mathrm{g} . / \mathrm{ml}$. for $3 \mathrm{hr}$ they showed a notable increase in lysozyme resistance; at the same time, their walls almost doubled in thickness. As lysozyme attack proceeded in a given culture, the bacilli passed first through a rod-shaped osmotically sensitive stage, and then a spherical stage characterized by incomplete removal of cell wall before finally reaching the naked protoplast stage. The spherical forms with adherent wall residues formed $\mathrm{L}$ colonies on a medium containing the reversion inhibitor D-methionine and bacillary colonies on the same medium without D-methionine. Under the latter conditions, the cell wall residue served as a starting point for rebuilding of complete wall, much as residual wall permits reversion of Gram-negative spheroplasts to the bacillary state. In the presence of Dmethionine, the feedback sequence required for wall formation was severed, resulting in heritable propagation of the protoplast state.
\end{abstract}

\section{INTRODUCTION}

The enzyme lysozyme hydrolyses the $\beta$-I,4 linkages between the muramic acid residues and the $N$-acetylglucosamine residues of bacterial cell-wall peptido-glycan. Peptido-glycan, a rigid material which holds bacilli to their characteristic shape and helps to protect them from osmotic shock, is found in almost all bacteria and in the blue-green algae. In the Gram-positive bacteria, peptido-glycan is generally a principal cell-wall component, while in Gram-negative bacteria the peptido-glycan or rigid layer is only one of several components which make up the complex wall (Salton, 1964). When Gram-positive bacteria such as Micrococcus lysodeikticus or Bacillus subtilis are subjected to lysozyme action, the wall is extensively depolymerized so that teichoic acid, the other major wall constituent, is freed and released into the supernatant fluid along with fragments of the peptido-glycan (Miller \& Landman, unpublished; Young, 1967). A spherical protoplast results which is bounded only by membrane and is apparently devoid of cell wall (Ryter \& Landman, 1964). When Gram-negative Escherichia coli organisms are treated with lysozyme, presumably only the rigid (innermost?) layer is attacked. The lipoprotein-containing outermost layer and the lipopolysaccharide-containing middle layer remain (Salton, 1964; Weidel, Frank \& 
Martin, I960). Nevertheless, having lost much of their rigid layer, these forms, called spheroplasts, are spherical in shape and sensitive to osmotic shock. Superimposed on this relatively simple and perhaps overgeneralized picture, there are numerous complexities due to differences among bacterial species. Further, as we shall show in this paper, the response to lysozyme of a single strain is clearly different at different times during growth.

Even greater changes in lysozyme sensitivity are produced by incubation of bacteria with antibiotics. It is well known that an important group of antibiotics attacks bacteria principally through damage of the cell envelope. This group includes penicillin, bacitracin, novobiocin, ristocetin, vancomycin, cycloserine, tyrocidin, gramicidin-S, and polymixin (Newton, 1965). Incubation of bacteria in the presence of any one of these substances could plausibly be expected to produce damage to the cell wall. In the present paper, we are concerned with changes in the cell wall produced by incubation with chloramphenicol (CAP), an antibiotic which is primarily an inhibitor of protein synthesis (Newton, 1965). In agreement with previous reports (Hash \& Davies, I962; Shockman, 1965), we have observed that prolonged inhibition of protein synthesis leads to a marked increase in the thickness of the cell wall. A sharp increase in lysozyme resistance was also noted in conjunction with CAP incubation or tryptophan starvation.

In studying the lysozyme-catalysed removal of cell wall from bacteria incubated with CAP it was found that a notable proportion of the bacteria from incompletely treated populations exhibited a plating behaviour intermediate between naked protoplats and intact bacilli. Like protoplasts, these forms gave rise to heritably stable $\mathbf{L}$ colonies on one type of plating medium (Landman \& Halle, 1963) and, like bacilli or spheroplasts of Gram-negative bacteria (Landman, Altenbern \& Ginoza, 1958), they produced bacillary colonies on a more favourable medium. The intermediate forms are thus on the borderline to commitment to the stable $\mathrm{L}$ state. A similar form has been detected in streptococcal populations incompletely treated with a wall-removing enzyme (King \& Gooder, 1965). A preliminary report of the present findings has already been published (Miller \& Landman, 1965).

\section{METHODS}

Organism. Bacillus subtilis strain 168 (indole $^{-}$) was used in all experiments.

Media. L forms and bacillary forms were grown on two plating media, DP and SDM. DP medium had the following composition: $0.02 \mathrm{I} \mathrm{M-K} \mathrm{K}_{2} \mathrm{HPO}_{4} ; 0.0 \mathrm{I}$ I M- $\mathrm{KH}_{2} \mathrm{PO}_{4}$; $0.5 \%$ acid-hydrolysed casein (Nutritional Biochemicals); $0.2 \%$ glucose; $0.002 \%$ L-tryptophan; $0.5 \mathrm{M}$-sodium succinate, $\mathrm{pH} 7.3 ; 0.005 \mathrm{M}-\mathrm{MgCl}_{2} ; 0.5 \%$ horse serum or human plasma; $0.9 \%$ agar. SDM medium was as DP medium except that $0.1 \%$ $\mathrm{NH}_{4} \mathrm{NO}_{3}$ replaced the casein hydrolysate as nitrogen source and $0.06 \% \mathrm{D}$-methionine was added to retard reversion of $\mathrm{L}$ forms. For dilutions of bacilli and protoplasts a hypertonic dilution fluid (DFR) was used; it had the following composition: $0.25 \mathrm{M}$ -

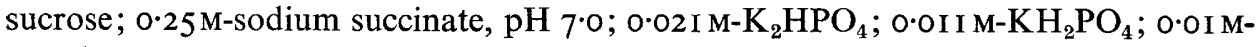
$\mathrm{MgCl}_{2} ; 0.0005 \mathrm{M}$-EDTA. The bacilli were grown successively on media SL 1 and SL2 (Landman \& Halle, I963) before treatment to form protoplasts. These media were the same as the competence media of Anagnostopoulos \& Spizizen (196I) except that medium SL 2 contained $0.5 \mathrm{M}$-sucrose to stabilize protoplasts. 
Growth of cultures. The procedure followed to prepare bacilli for treatment to give protoplasts paralleled the procedure used by Anagnostopoulos \& Spizizen (I96I) to render bacteria competent for transformation: spores of Bacillus subtilis I68 were inoculated onto plates of blood agar base medium (DIFCO), germinated, and incubated overnight at $37^{\circ}$. The confluent growth was harvested into a small volume of medium SL1 and adjusted with fresh medium to $45-50 \%$ transmission (at $670 \mathrm{~m} \mu$ ) in the Bausch \& Lomb Spectronic 20 Spectrophotometer; this turbidity corresponded to a colony count of about $\mathrm{I} \cdot 5 \times 10^{8}$ bacilli/ml. This culture was incubated with shaking at $37^{\circ}$ for $4 \mathrm{hr}$, then diluted $\mathrm{I} / \mathrm{IO}$ in medium SL2 and incubated with shaking at $37^{\circ}$ for a further $90 \mathrm{~min}$. These incubations were usually followed by further incubation in SL 2 medium without or with chloramphenicol $10-15 \mu \mathrm{g}$./ $\mathrm{ml}$. Samples of these bacilli were treated to give protoplasts at various times during these incubations, by adding lysozyme as indicated to $5 \mathrm{ml}$. volumes of bacillary suspension in SL2 medium in I $25 \mathrm{ml}$. Erlenmeyer flasks which were kept stationary in a water bath at $32-34^{\circ}$.

Colony counts quoted are averages based on 3-4 plates. Plates inoculated with protoplast-containing suspensions were incubated at $30^{\circ}$; plates from bacillary suspensions were incubated at $30^{\circ}$ or $37^{\circ}$.

Arrest of lysozyme action for differential phase microscope counts of spheres and rods. To assess the progress of sphere formation by phase microscopy at intervals during lysozyme treatment, it was important to arrest enzyme action abruptly. Formation of protoplasts in SL2 medium was stopped instantly upon adding an equal volume of $\mathrm{x} \%(\mathrm{w} / \mathrm{v}) \mathrm{OsO}_{4}$ in $0.5 \mathrm{M}$-sucrose. Differential counts in the Petroff-Hausser chamber had to be performed promptly since the spheres and osmotically sensitive bacilli began to lyse about $5 \mathrm{~min}$. after the $\mathrm{OsO}_{4}$ addition.

Procedure for electron microscopy. Five ml. of suspension of bacilli, protoplasts or 'protoplasting' bacilli were placed into a plastic centrifuge tube at $4^{\circ}$ and centrifuged for $20 \mathrm{~min}$. at $8000 \mathrm{~g}$. The pellet was rinsed 3 times with fresh SL 2 medium and suspended in 0. I $\mathrm{ml}$. SL 2 medium. Then $0.05 \mathrm{ml}$. of $4 \%(\mathrm{w} / \mathrm{v})$ glutaraldehyde (redistilled) in $0.1 \mathrm{M}$ cacodylate buffer ( $\mathrm{pH} \mathrm{6.0)}$ was added and the tube warmed to $45^{\circ}$. Molten $3 \%$ agar $(0.2 \mathrm{ml}$.) containing a $0.5 \times$ concentration of SL 1 salts and $0.5 \mathrm{M}$-sucrose was then mixed gently into the slurry. After the agar had cooled to room temperature, the plastic tube was cut open and the agar with the suspended organisms cut into $2-3 \mathrm{~mm} .{ }^{3}$ blocks which were fixed overnight in cacodylate-buffered $4 \%$ glutaraldehyde. The following day the agar blocks were washed in 3 changes of veronal buffer $(\mathrm{pH} 6)$ for a total of $3 \mathrm{hr}$, according to the procedure of Kellenberger, Ryter \& Séchaud (1958). Overnight fixation with $\mathrm{OsO}_{4}$, washing, treatment with uranyl acetate and further washing all were now followed according to the prescription of these authors. Finally, the blocks were dehydrated in graded concentrations of ethanol, washed twice for I 5 min. in propylene oxide and embedded in Epon (Luft, 1961). Sections, approximately $500 \AA$ in thickness, were cut with the MT I Porter-Blum microtome and stained for I min. in $0.2 \%$ lead citrate in $0.1 \mathrm{~N}-\mathrm{NaOH}$. The sections were examined in the RCA EMU $2 \mathrm{D}$ electron microscope.

\section{RESULTS}

Changes in lysozyme sensitivity during growth

When lysozyme is added to a suspension of Bacillus subtilis in hypertonic medium, the bacilli are gradually converted to protoplasts. These protoplasts give rise quantita- 
tively to $\mathrm{L}$ colonies when plated on certain soft agar media containing $0.5 \mathrm{M}-\mathrm{Na}$ succinate (Landman \& Halle, 1963). The rate of cell wall removal-and hence the rate of disappearance of bacillary-colony-forming elements and the rate of appearance of L-colony-forming units, 'commitment', depends on several factors. ('Commitment' was earlier defined as 'The point in time at which a cell loses its ability to give rise to a bacillary colony and gains its capacity to give rise to an L colony' (Landman \& Halle, 1963). With the demonstration in the present paper that a given cell may persist for some time in a borderline state from which it may give rise to either a bacillary colony or an L colony, this definition of commitment requires further refinement.) For example, lysozyme acts much more rapidly in sucrose-stabilized media than in succinate-containing media. Further, both lysozyme concentration and temperature markedly affect the rate of protoplast formation. Table I exhibits the effect of a more subtle variable on lysozyme sensitivity, namely, the previous growth history of the

\title{
Table I. Bacillus subtilis r68. Changes in sensitivity to lysozyme during competence incubation
}

\begin{abstract}
Organisms were grown for $4 \mathrm{hr}$ in medium SL1, diluted I/Io into medium SL2 and incubated further. At the times shown, samples were taken, subjected to 25 min. treatments with lysozyme $100 \mu \mathrm{g} . / \mathrm{ml}$. and plated on DP medium. The \% survival was obtained by comparing the total count of colonies (bacillary $+\mathrm{L}$ colonies) appearing on these plates with counts of untreated culture samples. A high $\%$ of $L$ colonies on the experimental plates is a reflexion of a high degree of sensitivity to lysozyme.
\end{abstract}

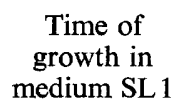
medium SL 1 (hr)

O

I

2

3

4

In medium SL2
0.5

$1 \cdot 5$

3
Experiment I

$\begin{array}{cc}\begin{array}{c}\text { Survival } \\ (\%)\end{array} & \begin{array}{c}\text { L colonies } \\ (\%)\end{array} \\ \text { I20 } & 2 \text { I } \\ 68 & 65 \\ \text { I I } 7 & 58 \\ \text { I06 } & \text { I } 8 \\ 99 & 6\end{array}$

\begin{tabular}{|c|c|}
\hline \multicolumn{2}{|c|}{ Experiment 2} \\
\hline $\begin{array}{c}\text { Survival } \\
(\%)\end{array}$ & $\begin{array}{c}\text { L colonies } \\
(\%)\end{array}$ \\
\hline 93 & I3 \\
\hline 75 & 98 \\
\hline 92 & 93 \\
\hline 84 & 54 \\
\hline 105 & 43 \\
\hline
\end{tabular}

bacteria. In the experiments shown, samples of culture were protoplasted at various times during the usual 'competence incubations' in SL 1 and SL 2 media (see Methods). Table I indicates that in SL1 medium the susceptibility to lysozyme increased to a maximum after I-2 hr of growth and then decreased again after I $-2 \mathrm{hr}$ of further incubation. During growth in SL2 medium, lysozyme sensitivity increased again. After $90 \mathrm{~min}$. of incubation (when the bacilli are highly competent for transformation) lysozyme sensitivity also reached a very high value. The two experiments presented in Table I show the same pattern of fluctuation of lysozyme sensitivity, but markedly different absolute values for the $\%$ of $\mathrm{L}$ colonies formed at different times. Further instances of consistent reproducibility of sensitivity patterns in the face of poor reproducibility of absolute sensitivity values are shown in subsequent Tables. We can offer no certain explanation for this phenomenon. 


\section{Effect of incubation in chloramphenicol media upon lysozyme sensitivity}

Changes in the lysozyme susceptibility of Bacillus subtilis 168 were particularly marked after prolonged incubation in media containing chloramphenicol (CAP). For example, in the experiment shown in Table 2 , CAP Io $\mu \mathrm{g}$. $/ \mathrm{ml}$. was added to highly sensitive competent bacilli after the $90 \mathrm{~min}$. incubation in SL2 medium. At the time of CAP addition (zero time) both experimental and control suspensions were attacked equally by lysozyme since, as expected, CAP did not affect the activity of this enzyme. However, as incubation in the presence of CAP proceeded, the bacilli became increasingly resistant to lysozyme. For example, after $3 \mathrm{hr}$ in SL2 medium + CAP, $40 \%$ of the organisms still gave bacillary colonies on DP plates after a $25 \mathrm{~min}$. lysozyme

\section{Table 2. Bacillus subtilis I68: development of lysozyme resistance during incubation in chloramphenicol}

Organisms were grown for $4 \mathrm{hr}$ in medium SL 1 and then for $90 \mathrm{~min}$. in medium SL2. At this time the colony count was $\mathrm{I} \cdot \mathrm{I} \times \mathrm{IO}^{8} / \mathrm{ml}$. The culture was divided and chloramphenicol (Io $\mu \mathrm{g} . / \mathrm{ml}$. final concentration) was added to one of the subcultures. Samples from both cultures were taken immediately and at hourly intervals and treated with lysozyme $100 \mu \mathrm{g} . / \mathrm{ml}$. for $25 \mathrm{~min}$. The treated samples and lysozyme-free controls were diluted in DFR and plated on DP and SDM plates. The development of lysozyme resistance during incubation in chloramphenicol medium is reflected in the increasing \% bacillary colonies remaining after lysozyme treatment.

\begin{tabular}{|c|c|c|c|c|c|c|c|c|}
\hline \multirow{3}{*}{$\begin{array}{l}\text { Time of } \\
\text { incu- } \\
\text { bation } \\
\text { (hr) }\end{array}$} & \multicolumn{4}{|c|}{ With chloramphenicol } & \multicolumn{4}{|c|}{ Without chloramphenicol } \\
\hline & \multicolumn{2}{|c|}{ DP medium } & \multicolumn{2}{|c|}{ SDM medium } & \multicolumn{2}{|c|}{ DP medium } & \multicolumn{2}{|c|}{ SDM medium } \\
\hline & $\begin{array}{c}\text { Survival } \\
(\%)^{*}\end{array}$ & $\begin{array}{c}\text { B colonies } \\
(\%) \dagger\end{array}$ & $\begin{array}{c}\text { Survival } \\
(\%)\end{array}$ & $\begin{array}{c}\text { B colonies } \\
(\%)\end{array}$ & $\begin{array}{c}\text { Survival } \\
(\%)\end{array}$ & $\begin{array}{c}\text { B colonies } \\
(\%)\end{array}$ & $\begin{array}{c}\text { Survival } \\
(\%)\end{array}$ & $\begin{array}{c}\text { B colonies } \\
(\%)\end{array}$ \\
\hline 0 & 80 & 2 & $8 \mathrm{I}$ & 0.7 & 87 & $I \cdot I$ & 71 & 0.8 \\
\hline I & 100 & 7 & 83 & $I \cdot 3$ & IIO & $1 \cdot 7$ & 82 & 0.8 \\
\hline 2 & 99 & 26 & I I9 & 3 & I08 & 0.8 & 96 & 0.2 \\
\hline 3 & 99 & 40 & 104 & 7 & 92 & 0.7 & 76 & $<0 . \mathrm{I}$ \\
\hline
\end{tabular}

$* \%=$ Ratio of total counts of bacillary $+\mathrm{L}$ colonies after lysozyme action to the counts before lysozyme treatment $\times 100$.

$\uparrow \% \mathrm{~B}=$ Ratio of number of bacillary colonies total number of colonies $\times 100$.

\section{Table 3. Bacillus subtilis 168: percentage of bacillary-colony formers among survivors of lysozyme treatment}

Organisms were pretreated and incubated in the presence or absence of chloramphenicol as shown for the $3 \mathrm{hr}$ samples in Table 2. A chloramphenicol-treated and a control culture were then incubated with lysozyme $200 \mu \mathrm{g} . / \mathrm{ml}$. and samples taken at intervals and plated on DP and SDM media. Survival averaged $93 \%$. Note the striking difference in lysozyme sensitivity of the two cultures. However, after I hr of lysozyme treatment the vast majority of the organisms in the resistant cultures had also become committed.

No treatment with chloramphenicol

Time of lyzosyme treatment (min.)

$\overbrace{25}^{30} \quad 3_{35}$

Treated with chloramphenicol for $3 \mathrm{hr}$.

Time of lyzosyme treatment (min.)

$\overbrace{2530} \overbrace{35 \quad 60}$

\begin{tabular}{lllllllll} 
Plating & \multicolumn{7}{c}{ bacillary-colony formers (\%) } \\
medium & $\overbrace{\text { DP }}^{<0.1}$ & $<0.1$ & $<0.3$ & $<0.1$ & 80 & 63 & 52 & 4 \\
SDM & $<0.2$ & $<0.2$ & $<0.1$ & $<0.2$ & 44 & 34 & 19 & 2
\end{tabular}


treatment. By contrast, sensitivity to lysozyme continued to increase in the control populations incubated in parallel in SL 2 medium without CAP. It should be stressed that the lysozyme resistance which was manifest in the $3 \mathrm{hr}$ CAP-incubated culture was not absolute: when the lysozyme treatment was continued long enough, virtually all of the bacilli even in this population become committed to the L-state. This is shown in Table 3.

The marked increase in lysozyme resistance due to incubation with CAP suggested that it might be possible to observe by electron microscopy correlated changes in the thickness of the cell walls. Accordingly, thin sections of CAP-incubated and of control bacilli were examined in the electron microscope. The results (Pl. I, fig. 1, 2, Table 4) clearly indicate that a thickening in the cell wall occurred during the $3 \mathrm{hr}$ incubation in SL2 medium + CAP. On the average, the wall of the CAP-incubated bacilli was $\mathrm{I} \cdot 9$ times as thick as that of the controls (Table 4). The electron micrographs of the CAP-incubated organisms show that the thickness of the cell wall had increased fairly uniformly all around the bacilli.

\section{Table 4. Bacillus subtilis I68: average wall thickness of chloramphenicol-treated} and untreated bacilli

Electronmicrographs $\times 103,000$ of 30 randomly chosen bacilli were used to compile each of the 2 sets of figures. Each number is an average of ten measurements. The deviations shown are standard deviations. The difference between the two sets of measurements is significant $(P<0.001)$.

\begin{tabular}{|c|c|c|}
\hline & $\begin{array}{l}\text { ramphenicol } \\
\text { treated }\end{array}$ & Untreated \\
\hline & Wall thick & ess $(\AA)$ \\
\hline & 268 & 150 \\
\hline & 295 & 160 \\
\hline & 275 & 142 \\
\hline & 305 & I43 \\
\hline & 284 & 145 \\
\hline & 295 & 140 \\
\hline & 292 & 160 \\
\hline & 268 & 155 \\
\hline & 289 & 150 \\
\hline & 289 & 155 \\
\hline Average thickness & $268 \pm 47$ & $150 \pm 29$ \\
\hline
\end{tabular}

\section{Effect of tryptophan deprivation on lysozyme resistance}

Blockage of protein synthesis by CAP presumably causes accumulation of unused amino acids (Hancock \& Park, I958) and, possibly, diversion of some of these amino acids into cell-wall synthesis. If this view be correct, starvation for tryptophan, which is not a constituent of Bacillus subtilis cell walls (Young, Spizizen \& Crawford, 1963) should mimic the effect of incubation with CAP. As shown in Table 5, omission of tryptophan from SL 2 medium did cause the development of increased resistance to lysozyme. However, tryptophan starvation was notably less effective than incubation with CAP and, in a combination of the two treatments, the CAP effect predominated. Examination of thin sections of tryptophan-starved and control bacilli in the electron microscope has shown that thickening of the cell wall also occurs as a result of tryptophan starvation (L. J. Archer \& G. B. Chapman, unpublished). 
Table 5. Bacillus subtilis I68: effect of tryptophan deprivation and chloramphenicol on lysozyme sensitivity

Organisms were grown in SL1 medium for $4 \mathrm{hr}$ and then in SL 2 medium for 90 min. After removal of the o time sample, the culture was divided into 4 portions ( \pm tryptophan, \pm chloramphenicol) as shown and incubated for another $4 \mathrm{hr}$. All cultures were treated with lysozyme $200 \mu \mathrm{g} . / \mathrm{ml}$. for $25 \mathrm{~min}$. immediately after sampling and then plated on DP and SDM media.

\begin{tabular}{|c|c|c|c|c|c|c|c|}
\hline \multirow{2}{*}{$\begin{array}{c}\text { Time of } \\
\text { sampling } \\
\text { (hr) }\end{array}$} & \multicolumn{2}{|c|}{ Treatment } & \multirow[b]{2}{*}{$\begin{array}{l}\text { Plating } \\
\text { medium }\end{array}$} & \multicolumn{2}{|c|}{ Experiment I } & \multicolumn{2}{|c|}{ Experiment 2} \\
\hline & $\begin{array}{c}\text { Trypto- } \\
\text { phan }\end{array}$ & $\begin{array}{l}\text { Chloram- } \\
\text { phenicol }\end{array}$ & & $\begin{array}{c}\text { Survival } \\
(\%)^{*}\end{array}$ & $\begin{array}{c}\text { B colonies } \\
(\%) \dagger\end{array}$ & $\begin{array}{c}\text { Survival } \\
(\%)\end{array}$ & $\begin{array}{c}\text { B colonies } \\
(\%)\end{array}$ \\
\hline 0 & - & - & $\begin{array}{l}\text { DP } \\
\text { SDM }\end{array}$ & $\begin{array}{r}125 \\
73\end{array}$ & $\begin{array}{l}1 \cdot 60 \\
0.57\end{array}$ & $\begin{array}{l}50 \\
33\end{array}$ & $\begin{array}{l}0.30 \\
0.22\end{array}$ \\
\hline 4 & + & - & $\begin{array}{l}\text { DP } \\
\text { SDM }\end{array}$ & $\begin{array}{l}23 \\
29\end{array}$ & $\begin{array}{l}<0.56 \\
<0.45\end{array}$ & $\begin{array}{l}30 \\
21\end{array}$ & $\begin{array}{l}0.44 \\
0.1 \text { I }\end{array}$ \\
\hline 4 & - & - & $\begin{array}{l}\text { DP } \\
\text { SDM }\end{array}$ & $\begin{array}{l}92 \\
86\end{array}$ & $\begin{array}{l}14 \\
12\end{array}$ & $\begin{array}{l}77 \\
60\end{array}$ & $\begin{array}{r}5.2 \\
<0.2\end{array}$ \\
\hline 4 & + & + & $\begin{array}{l}\text { DP } \\
\text { SDM }\end{array}$ & $\begin{array}{l}91 \\
94\end{array}$ & $\begin{array}{l}80 \\
43\end{array}$ & $\begin{array}{l}71 \\
62\end{array}$ & $\begin{array}{l}32 \\
7 \cdot 1\end{array}$ \\
\hline 4 & - & + & $\begin{array}{l}\text { DP } \\
\text { SDM }\end{array}$ & $\begin{array}{l}95 \\
96\end{array}$ & $\begin{array}{l}77 \\
43\end{array}$ & $\begin{array}{l}74 \\
60\end{array}$ & $\begin{array}{l}19 \\
5 \cdot 8\end{array}$ \\
\hline
\end{tabular}

$* \%=$ ratio of counts of bacillary $+\mathbf{L}$ colonies after lysozyme action to counts before lysozyme treatment $\times 100$.

$\dagger \% \mathrm{~B}=$ ratio of number of bacillary colonies to total number of colonies $\times 100$.

\section{Transient appearance of a spheroplast-like form during protoplasting of Bacillus subtilis 168}

A conspicuous feature of the data in Tables 2, 3 and 5 is the discrepancy between the percentage of bacillary colonies observed on DP medium and those counted on SDM medium. For example, Table 2 shows that after $3 \mathrm{hr}$ incubation in SL 2 medium + CAP, a $25 \mathrm{~min}$. lysozyme treatment produced a suspension which gave $40 \%$ of bacillary colonies on DP medium and $7 \%$ of bacillary colonies on SDM medium. Since survival was complete, it must be concluded that $33 \%$ of the total population scored as 'committed to the L state' on SDM medium and as 'bacillary' on DP medium. Control experiments with media lacking either casein hydrolysate or D-methionine have shown that $\mathrm{D}$-methionine is responsible for the difference in the plating behaviour of the intermediate form on the two media. The D-amino acid, a reversion inhibitor (Landman \& Halle, 1963), apparently prevents repairs in the lysozyme-damaged walls which are required for the continued maintenance of the bacillary state (Landman, 1967). The intermediate form is characteristic of suspensions incompletely changed to protoplasts and is not restricted to populations which have been pretreated by incubation with CAP. In more lysozyme-sensitive cultures, a briefer lysozyme treatment can be used to show the phenomenon (Table 6).

Since the intermediate form is obtained when the removal of cell wall is incomplete, it became of interest to know whether such forms appeared as spheres or as rods in the phase microscope. The experiments recorded in Table 7 were made to answer this question. In the first of the experiments, microscopic counts of spherical, spheroidal and rod forms were made for a population which, according to its subsequent plating 
behaviour, contained about $16 \%$ intermediate forms and $3 \%$ completely committed forms. The microscopic counts gave $18 \%$ 'true' spheres and $82 \%$ rods + spheroids; clearly, therefore, the intermediate forms appeared to be completely spherical in the phase microscope. In the second experiment the microscopic observations and platings were made after lysozyme action had proceeded much further. However, the results

\section{Table 6. Bacillus subtilis 168: appearance of intermediate form during brief exposure of sensitive organisms to lysozyme}

Organisms were grown in SL1 medium for $4 \mathrm{hr}$ and then in SL2 medium for $90 \mathrm{~min}$. Lysozyme was then added to $250 \mu \mathrm{g}$. $/ \mathrm{ml}$., samples were taken at times shown, then immediately diluted, and plated on DP and SDM media. Intermediate forms are those organisms which form $\mathrm{L}$ colonies on SDM medium and bacillary colonies on DP medium (e.g. $29 \%$ of the organisms were in the intermediate form after $10 \mathrm{~min}$. of incubation.)

\begin{tabular}{|c|c|c|c|c|c|}
\hline \multirow[b]{2}{*}{$\begin{array}{l}\text { Plating } \\
\text { medium }\end{array}$} & \multicolumn{5}{|c|}{$\begin{array}{c}\text { Duration of lysozyme treatment } \\
\text { (min.) }\end{array}$} \\
\hline & 10 & $\begin{array}{r}\mathbf{I} 5 \\
\text { bacilla }\end{array}$ & 20 & $\begin{array}{l}25 \\
(\%)\end{array}$ & 30 \\
\hline DP & 63 & 38 & 24 & 9 & 4 \\
\hline SDM & 34 & 17 & 7 & 4 & 2 \\
\hline
\end{tabular}

Table 7. Bacillus subtilis 168 : relationship between plating behaviour and morphology in populations forming protoplasts

The bacilli were subjected to the usual competence procedure, then chloramphenicol was added and incubation continued in SL 2 medium for $3 \mathrm{hr}$ more (2.5 hr in Expt. 2). After o time platings, lysozyme was added to a final concentration $200 \mu \mathrm{g} . / \mathrm{ml}$.; 20 (or 25 ) min. later samples were taken for platings. $\mathrm{OsO}_{4}$ was added to block instantly further changes in morphology and Petroff-Hausser total counts were made immediately.

\begin{tabular}{|c|c|c|c|c|c|c|c|}
\hline \multicolumn{8}{|c|}{ Columns } \\
\hline I & 2 & 3 & $\stackrel{4}{\text { Plating data }}$ & 5 & 6 & 7 & 8 \\
\hline \multirow[b]{2}{*}{$\begin{array}{c}\text { Expt. } \\
\text { no. }\end{array}$} & \multirow{2}{*}{$\begin{array}{l}\text { Proto- } \\
\text { plasting } \\
\text { time } \\
\text { (min.) }\end{array}$} & \multirow{2}{*}{$\begin{array}{c}\mathrm{L} \text { colonies } \\
\text { on DP } \\
\text { medium } \\
(\%)\end{array}$} & \multirow{2}{*}{$\begin{array}{l}\text { L colonies } \\
\text { on SDM } \\
\text { medium } \\
(\%)\end{array}$} & \multirow{2}{*}{$\begin{array}{l}\text { inter- } \\
\text { mediate } \\
\text { forms } \\
(\%)\end{array}$} & \multicolumn{3}{|c|}{ Microscope counts } \\
\hline & & & & & $\begin{array}{r}\text { rods } \\
(\%)\end{array}$ & $\begin{array}{c}\text { spheroids } \\
(\%)\end{array}$ & $\begin{array}{c}\text { spheres } \\
(\%)\end{array}$ \\
\hline \multirow[t]{2}{*}{ I* } & o & 0 & 0 & 0 & 100 & 0 & 0 \\
\hline & 20 & 3 & 19 & I6 & 77 & 4 & I 8 \\
\hline \multirow[t]{2}{*}{$2+$} & 0 & 0 & 0 & 0 & 100 & 0 & 0 \\
\hline & 25 & $9 \mathrm{I}$ & 99 & 8 & I & 3 & 96 \\
\hline
\end{tabular}

* The number of perfect spheres seen in the phase microscope (col. 8) far exceeded the number of completely committed protoplasts (col. 3). Further, the \% spheres (col. 8) was about the same as the combined $\%$ of committed forms and intermediate forms (col. 3 and 5 or col. 4 ). Hence it is concluded that the intermediate forms were spherical in shape.

$\dagger$ The \% intermediate forms (col. 5) considerably exceeded the combined count of rods and spheroids (cols. 6 and 7). Hence it is concluded that the intermediate forms were spherical in shape.

led to the same conclusion, namely, that the intermediate forms were spherical. In Expt. 2 the number of intermediate forms was considerably greater than the sum of remaining rod and spheroid forms counted in the microscope.

Plate 2, figs. 3-5 show electron micrographs of spherical forms from populations 
which had been treated with lysozyme for, respectively, 20 and $30 \mathrm{~min}$. and which contained $29 \%$ or $23 \%$ intermediate forms. Considerable portions of the surface of the pictured forms are covered with a thinned residual layer of wall. In an earlier experiment, in which a larger number of organisms was photographed, 33 out of a total of 60 spherical forms retained residual cell-wall material. In this latter experiment, $33 \%$ of the population behaved as intermediate forms, and $46 \%$ as committed forms. In the three electron-microscopic surveys of intermediate populations which were made, the residual wall usually adhered fairly closely to the underlying protoplasts in a manner similar to that shown in P1. 2, figs. 3-5. However, we also observed separation of cell-wall 'casings' from protoplasts, a phenomenon which had been seen earlier in studies of protoplasting on solid media (Ryter \& Landman, I964). A typical form from an extensively ( $80 \mathrm{~min}$.) lysozyme-treated population is shown in P1. 2, fig. 6. Of this population, $90 \%$ behaved as committed forms; no cell-wall residues were observed.

\section{DISCUSSION}

The observations described in this paper concern several different topics, namely, changes in the cell wall of Bacillus subtilis 168 during normal growth, changes in the cell wall produced by inhibition of protein synthesis by chloramphenicol, and the relationship of cell-wall removal to commitment to the $\mathrm{L}$ state. These topics will be discussed in turn.

There are reports that, in a given bacterial species, changes in the cell wall may be produced not only by changing the medium of cultivation (Martin, I966; Whitney \& Grula, I964; Young, 1965), but differences can occur also in the course of the regular growth cycle (Young, 1965). Further, subtle changes in the cell surface which develop under some conditions during growth are apparently responsible for competence in transformation. In competence development in Pneumococcus and Streptococcus, chemically and serologically identifiable materials appear quite abruptly in growing cultures, and again disappear, at least partly as a result of enzymic action (Tomasz \& Hotchkiss, 1964; Tomasz \& Beiser, 1965; Pakula \& Walczac, 1963). With Bacillus subtilis, wall-surface modifications also have been reported to accompany changes in competence (Charpak \& Dedonder, 1965; Jensen \& Haas, 1963; Young, 1965; Young, 1966); again these variations occur well within the compass of a few divisions or, indeed, in the absence of division (Archer \& Landman, 1967). The changes in lysozyme sensitivity which we have observed sometimes run parallel with changes in competence. In lysozyme sensitivity, as in competence, the changes are quite rapid and substantial variations may occur without division or in $\mathrm{I}$ or 2 divisions. It is likely that the wall-associated autolytic enzyme acetylmuramyl-L-alanine amidase (Young, I965), which has been tentatively implicated in competence development, plays a role in effecting these variations. Further, enzymes of this type may also enhance or modify the protoplast-formation action of lysozyme in the various samples (Shockman, 1967). In any case, if the varying rates of commitment of organisms growing in SL 1 and SL 2 media are indeed a reflexion of changes in the structural and enzymic constitution of the cell wall, it must be concluded that the walls of growing B. subtilis are in a state of almost continual change.

When the metabolism of Bacillus subtilis is altered by inhibition of protein synthesis, cell wall changes become even more pronounced. In the terminology of Shockman 
(1965), inhibition of protein synthesis produces a state of unbalanced growth which permits continued increase in cell-wall substance while blocking an increase in protein. The increase in cell-wall substance relative to cytoplasmic substance is clearly indicated by the increase in wall thickness observed in the electron microscope. Analogous increases in wall thickness in Streptococcus faecalis during both CAP treatment and starvation for threonine or valine were described by Shockman (1965). Tetracycline, another protein synthesis inhibitor, has been shown to produce thickening of cell walls in Staphylococcus aureus (Hash \& Davies, 1962). (Incubation in tetracycline media also causes development of lysozyme-resistance in B. subtilis, I. L. Miller, unpublished.)

We know little about the comparative chemical make-up of normal cell walls and the abnormal walls produced under conditions of inhibition of protein synthesis. However, it seems to us unlikely that the great differences in lysozyme sensitivity which we have observed could be due exclusively to even a 2- to 3 -fold increase in thickness of cell wall; it seems much more probable that changes in cell-wall composition are also involved. For one thing, the formation of wall-associated autolytic enzymes (Shockman, I965; Young, I966) is almost certainly blocked by chloramphenicol (CAP). If autolytic enzymes play a complementary role with lysozyme depolymerization of normal wall, the slowed lysis of presumably autolysin-depleted CAP-treated organisms may be more easily understood. The assumed lowering in the concentration of autolytic enzymes may also be invoked to explain the unexpected observation that wall thickening in CAP-incubated bacilli was almost uniform all-round the periphery of the organism. A localized thickening might have been anticipated on the basis of the observations of Chung, Hawirko \& Isaac (1964) and of Cole (I965) that cell-wall growth in Gram-positive bacteria occurs in localized regions. The partial absence of localized autolysins required for the loosening of expanding cell walls (Shockman, I965; Young, 1966) might explain an abnormal uniformity in the deposition of wall during CAP trcatment.

In addition to modifying the enzyme content of cell walls, the inhibition of protein synthesis alters the pool concentration (Hancock, 1960) and metabolic flow of amino acids. As a result, the peptide content of the wall, the relationship of peptide content to teichoic acid content, and the cross-linking between wall constituents may well be changed. In Streptococcus faecalis, a quantitative difference between the amino acid content of the walls of threonine-deprived and of normal cocci has been described (Toennies, Bakay \& Shockman, 1955). However, in Staphylococcus aureus, growth in presence of CAP did not appear to modify the composition of the cell wall, although wall synthesis continued throughout the CAP treatment period (Hancock \& Park, I958).

In their discussion of the process of protoplast formation, Landman \& Halle (1963) distinguished an intermediate between bacillus form and protoplast, namely a rodshaped osmotically sensitive form which did not survive in hypotonic media but gave bacillary colonies on hypertonic plating medium. In the present paper a succeeding intermediate form is recognized: a sphere-shaped form which gave a bacillary colony on DP medium and produced an L colony on SDM medium. In the upper portion of Table 8 the characteristics of the various forms are summarized. The lower portion of Table 8 shows the appearance and disappearance of the different forms as observed during a typical experiment on protoplast formation. The gradual progression from the bacillary state through the first and then the second intermediate form to the protoplast 
state is clearly evident from the shifting percentage composition of the population undergoing lysozyme treatment (Table 8 , lower right).

From the point of view of commitment, the second intermediate forms are very interesting since they are evidently able to re-initiate cell-wall formation on DP medium, but not on SDM medium. The primer mechanism which is responsible for this wall re-initiation (Landman, I967; Landman \& Halle, 1963) is apparently present vestigially in these forms. We suggest that the residues of cell wall which are visible in

\section{Table 8. Bacillus subtilis 168}

Stages of protoplast formation: schematic

\begin{tabular}{llccc}
\multicolumn{1}{c}{ Stage } & $\begin{array}{c}\text { Osmotic } \\
\text { sensitivity }\end{array}$ & $\begin{array}{c}\text { Morphology } \\
\text { in phase } \\
\text { microscope }\end{array}$ & $\begin{array}{c}\text { Colony form } \\
\text { on DP } \\
\text { medium }\end{array}$ & $\begin{array}{c}\text { Colony form } \\
\text { on SDM } \\
\text { medium }\end{array}$ \\
Bacillus & $\begin{array}{l}\text { Insensitive } \\
\text { Ist intermediate form }\end{array}$ & Rod & Bacillary & Bacillary \\
2nd intermediate form & Sensitive & Rod & Bacillary & Bacillary \\
Protoplast: committed form & Sensitive & Sphere & Bacillary & L-form \\
& Sensitive & Sphere & L-form & L-form
\end{tabular}

Stages of protoplast formation: experimental

\begin{tabular}{|c|c|c|c|c|c|c|c|c|c|c|}
\hline \multirow[b]{4}{*}{ Predominant stage } & \multirow{4}{*}{$\begin{array}{c}\text { Time of } \\
\text { lysozyme } \\
\text { treat- } \\
\text { ment* }\end{array}$} & \multicolumn{5}{|c|}{ Colony counts $\left(\times \mathrm{IO}^{-6} / \mathrm{ml}.\right)$} & \multirow{2}{*}{\multicolumn{4}{|c|}{$\begin{array}{c}\begin{array}{c}\text { Among survivors: } \\
\text { approximate }\end{array}\end{array}$}} \\
\hline & & \multirow{3}{*}{$\begin{array}{c}\text { On low } \\
\text { salt } \dagger\end{array}$} & \multirow{2}{*}{\multicolumn{2}{|c|}{$\begin{array}{c}\text { On } \\
\text { DP med. }\end{array}$}} & \multirow{2}{*}{\multicolumn{2}{|c|}{$\begin{array}{c}\text { On } \\
\text { SDM med. }\end{array}$}} & & & & \\
\hline & & & & & & & \multirow{2}{*}{$\begin{array}{l}\mathrm{B} \\
(\%)\end{array}$} & \multirow{2}{*}{$\begin{array}{c}\text { Ist } \\
\text { form } \\
(\%)\end{array}$} & \multirow{2}{*}{$\begin{array}{c}\text { 2nd } \\
\text { form } \\
(\%)\end{array}$} & \multirow{2}{*}{$\begin{array}{c}\mathbf{P} \\
(\%)\end{array}$} \\
\hline & & & Bł & $\mathbf{L} \S$ & B & $\mathbf{L}$ & & & & \\
\hline Bacillus & $\circ$ & 95 & IOI & - & 89 & 一 & 100 & - & - & - \\
\hline Ist intermediate form & 20 & $4 \cdot 2$ & 79 & $7 \cdot 5$ & 53 & 32 & 5 & 57 & 29 & 9 \\
\hline $\begin{array}{l}\text { Ist and 2nd inter- } \\
\text { mediate forms }\end{array}$ & 25 & $\mathrm{I} \cdot 2$ & 67 & 16 & 33 & 42 & 2 & 40 & 38 & 20 \\
\hline $\begin{array}{l}\text { 2nd form and proto- } \\
\text { plast }\end{array}$ & 30 & 0.8 & 48 & 32 & I5 & 43 & $\mathbf{I}$ & 20 & 33 & 46 \\
\hline Protoplast & 35 & $\mathrm{I} \cdot 5$ & 37 & 38 & 8 & 50 & 2 & Io & $3 \mathrm{r}$ & 57 \\
\hline Protoplast & 40 & 0.5 & 25 & 39 & 5 & 50 & $<$ I & 8 & 27 & 65 \\
\hline Protoplast & 45 & 0.3 & 12 & 42 & 3 & 52 & $<2$ & 4 & 17 & 76 \\
\hline
\end{tabular}

* Organisms incubated with chloramphenicol ( $15 \mu \mathrm{g} . / \mathrm{ml}$.) medium for $3 \mathrm{hr}$ before protoplast formation with lysozyme concentration $200 \mu \mathrm{g}$. $/ \mathrm{ml}$.

$\dagger$ Hypotonic medium was DP medium without succinate. Colony counts shown are actual counts $\times 10^{-6}$.

$\ddagger$ Bacillary colonies.

$\S$ L-form colonies.

PI. 2, figs. 3-5 constitute the vestigial primer. How this vestigial primer accomplishes its priming functions is not known; it might do so directly by serving as a nucleus of attachment for further wall synthesis or wall fragments might indirectly serve as primers by facilitating other priming events in adjacent areas of the cell membrane. In any case, re-initiation of cell-wall formation in these incompletely formed protoplasts, unlike the reversion of protoplasts, takes place promptly and efficiently in ordinary media. The difficult initial event required for the reversion of protoplasts and stable L-forms is avoided. However, it is possible that in later phases of protoplast reversion the reverting forms pass through a stage resembling the second intermediate form (see Landman, 1967; Ryter \& Landman, 1967).

The second intermediate form presents an interesting parallel with the spheroplasts 
of Gram-negative bacteria. Both forms are osmotically sensitive spheres, both retain important quantities of cell-wall material and both revert promptly to the bacillary form as soon as the removal of cell wall is interrupted (i.e. both retain priming activity). In both forms, further removal of wall leads to loss of primer and thereby to an heritably persistent L-state (Landman \& Ginoza, 196r ; Landman \& Halle, I963). The second intermediate form of Bacillus subtilis I 68 differs from spheroplasts of Gramnegative bacteria mainly by its lack of persistence under present experimental conditions.

Dr Masaya Kawakami kindly assisted in making the phase microscope counts of intermediate forms and Dr G. Chapman gave advice and help in making the electron micrographs. This work was supported by grants AI 05972 from the National Institutes of Health (USA), GB I875 from The National Science Foundation (USA), and by a U.S. Public Health Predoctoral Fellowship, IFI-GM33, 752-OI for Mr R. Zsigray.

\section{REFERENCES}

Anagnostopoulos, C. \& Spizizen, J. (1961). Requirements for transformation in Bacillus subtilis. J. Bact. 8I, 74I.

ARCHER, L. J. \& LANDMAN, O. E. (1967). Transformation of unlinked loci in synchronized Bacillus subtilis cultures with chromosomes arrested at the origin. Bact. Proc. p. 52.

Charpak, M. \& Dedonder, R. (1965). Production d'un 'facteur de competence' soluble par $B$. subtilis Marburg ind-168. C. r. hebd. Séanc. Acad. Sci., Paris, 260, 5638.

Chung, K. L., Hawirko, R. Z. \& IsaAC, P. K. (1964). Cell wall replication. I. Cell wall growth of B. cereus and B. megaterium. Can. J. Microbiol. 1o, 43.

CoLE, R. M. (1965). Bacterial cell wall replication followed by immunofluorescence. Bact. Rev. 29, 326.

FITZ-JAMES, P. C. (I967). The isolation of mesosomal vesicles extruded during protoplasting. In Microbial Protoplasts, Spheroplasts and L-Forms. Ed. by L. B. Guze. Baltimore: Williams and Wilkins.

HANCOCK, R. (1960). Accumulation of pool amino acids in Staphylococcus aureus following inhibition of protein synthesis. Biochim. biophys. Acta. 37, 47.

Hancock, R. \& PARK, J. T. (1958). Cell wall synthesis by S. aureus in the presence of chloramphenicol. Nature, Lond. 181, 1050.

HaSH, J. H. \& Davies, M. C. (1962). Electron microscopy of Staphylococcus aureus treated with tetracycline. Science, N.Y. 138, 828 .

Jensen, R. H. \& HAAS, F. (1963). Electrokinetics and cell physiology. II. Relationship of surface change to onset of bacterial competence for genetic transformation. J. Bact. 86, 79.

KELLENBERGER, E., RYTER, A. \& SÉCHAUd, J. (1958). Electron microscope study of DNA-containing plasms. II. Vegetative and mature phage DNA as compared with normal bacterial nucleoids in different physiological states. J. biophys. biochem. Cytol. 4, $67 \mathrm{x}$.

KING, J. R. \& Gooder, H. (1965). Subsequent growth as L-forms or streptococci of lysozymedamaged group D streptococci. Bact. Proc. p. 58.

Landman, O. E. (1967). Protoplasts, spheroplasts and L-forms viewed as a genetic system. In Microbial Protoplasts, Spheroplasts and L-Forms. Ed. by L. G. Guze. Baltimore: Williams and Wilkins.

Landman, O. E. \& Ginoza, H. S. (1961). Genetic nature of stable L-forms of Salmonella paratyphi. J. Bact. 8I, 875 .

LANDMAN, O. E. \& HaLle, S. (1963). Enzymically and physically induced inheritance changes in Bacillus subtilis. J. molec. Biol. 7, 72 r.

Landman, O. E., Altenbern, R. A. \& Ginoza, H. S. (1958). Quantitative conversion of cells and protoplasts of Proteus mirabilis and Escherichia coli to the L-form. J. Bact. 75, 567.

LUFT, J. H. (196I). Improvements in epoxy resin embedding methods. J. biophys. biochem. Cytol. 9 409. 
Journal of General Microbiology, Vol. 49, No. 3

Plate I
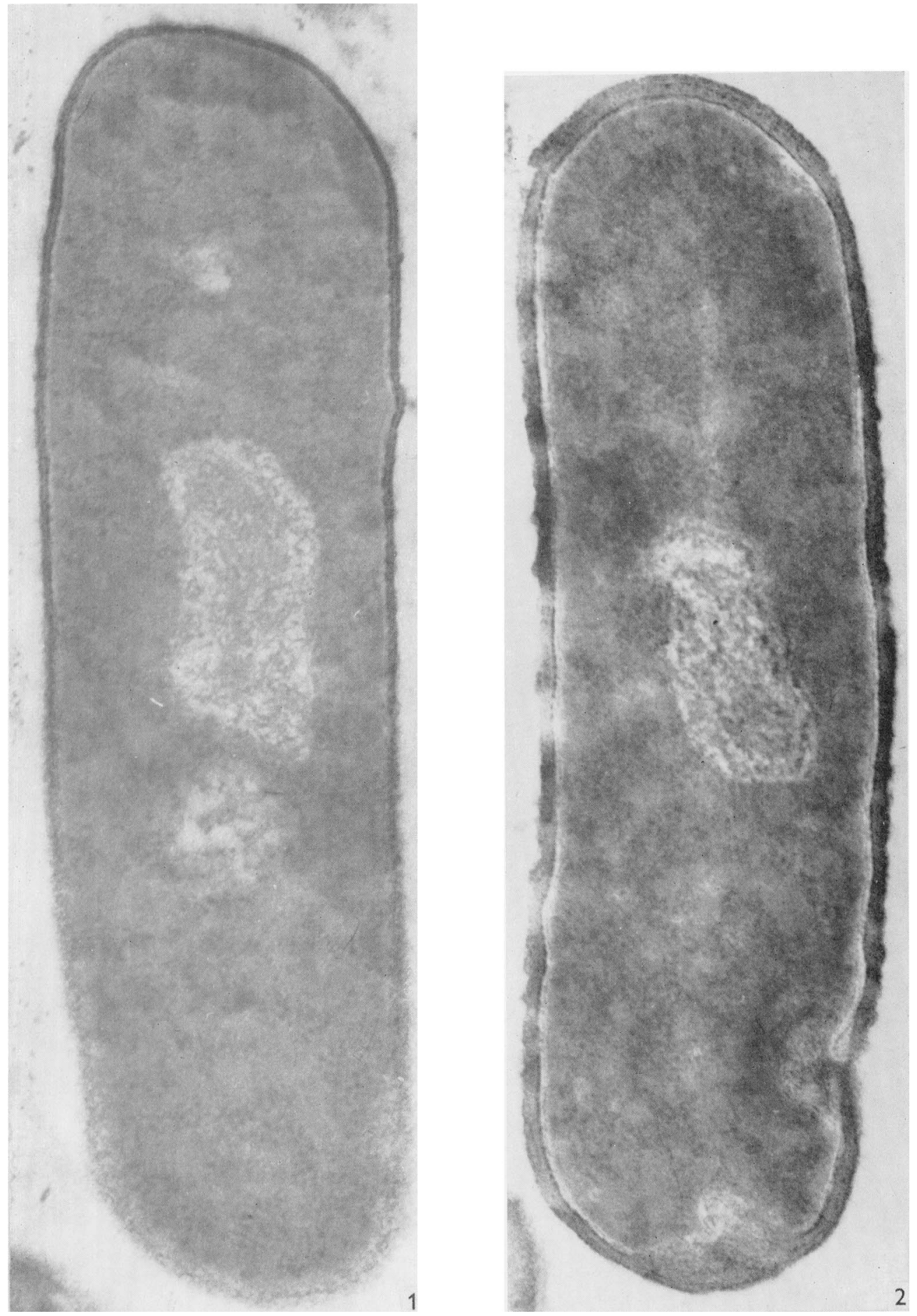

I. L. MILLER, R. M. ZSIGRAY AND O. E. LANDMAN

(Facing p. 524) 
Journal of General Microbiology, Vol. 49, No. 3

Plate 2
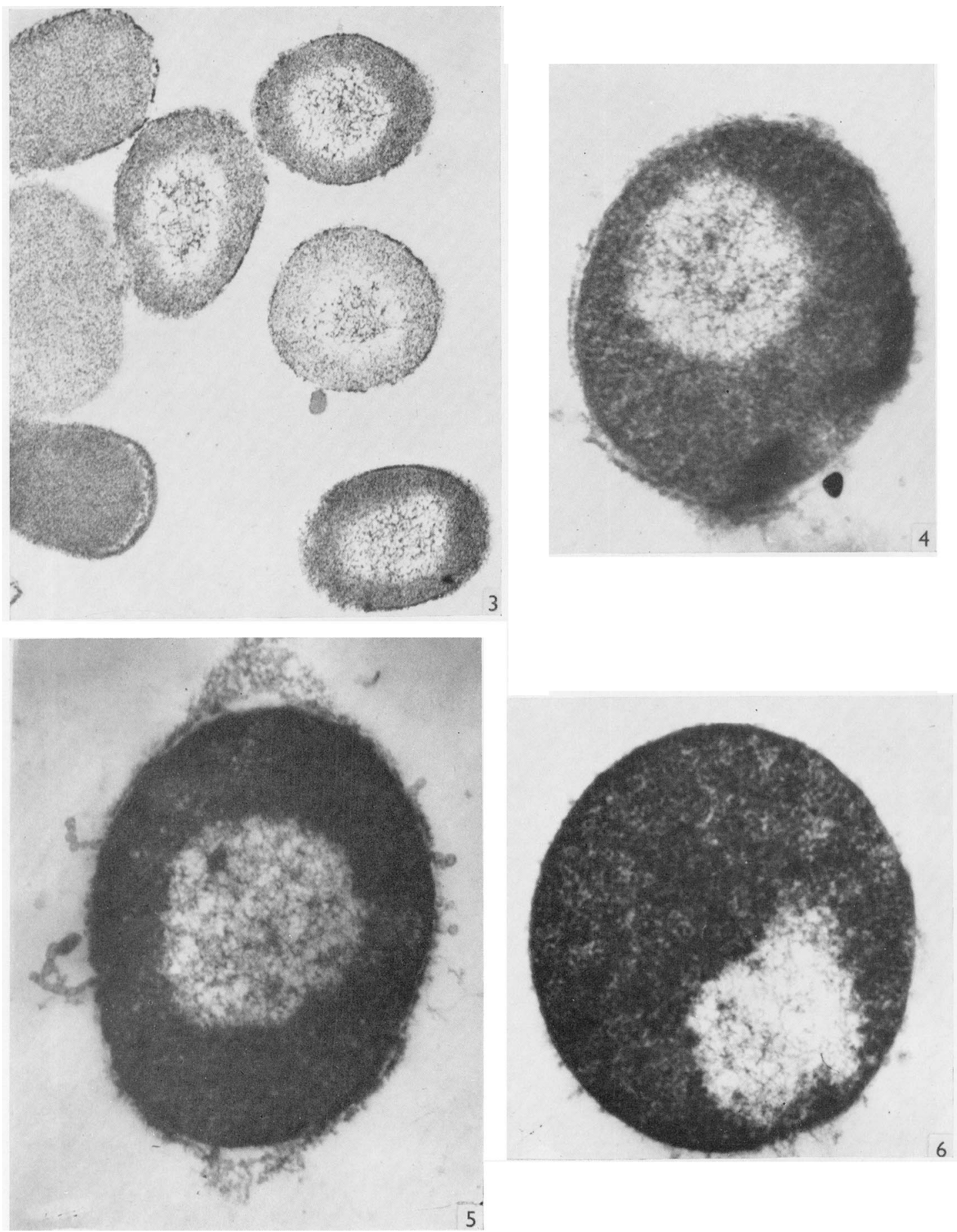

I. L. MILLER, R. M. ZSIGRAY AND O. E. LANDMAN 
Martin, H. H. (I966). Biochemistry of bacterial cell walls. A. Rev. Biochem. 35, 457.

Miller, I. L. \& Landman, O. E. (1965). The effect of chloramphenicol pretreatment of Bacillus subtilis on its cell wall and lysozyme spheres. Bact. Proc. p. 27.

Newton, B. A. (1965). Mechanism of antibiotic action. A. Rev. Microbiol. 19, 209.

Pakula, R. \& Walczac, W. (1963). On the nature of competence of transformable Streptococci. $J$. gen. Microbiol. 31, I25.

RYTER, A. \& LANDMAN, O. E. (1964). Electron microscope study of the relationship between mesosome loss and the stable L-state (or protoplast state) in Bacillus subtilis. J. Bact. 88, 457.

RYTER, A. \& LANDMAN, O. E. (1967). Morphological study of the attachment of nucleoid to membrane in bacilli, protoplasts and reverting protoplasts of Bacillus subtilis. In Microbial Protoplasts, Spheroplasts and L-Forms. Ed. by B. Guze. Baltimore: Williams and Wilkins.

Salton, M. R. J. (1964). The Bacterial Cell Wall. Amsterdam: Elsevier.

Shockman, G. D. (1965). Unbalanced cell wall synthesis: autolysis and cell-wall thickness. Bact. Rev. 29, 345 .

Shockman, G. D. (1967). The relationship of autolysin to lysozyme sensitivity of Streptococcus faecalis. In Microbial Protoplasts, Spheroplasts and L-Forms. Ed. by B. L. Guze. Baltimore: Williams and Wilkins.

Tomasz, A. \& Beiser, S. M. (1965). Relationship between the competence antigen and the competence-activator substance in Pneumococci. J. Bact. 90, 1226.

Tomasz, A. \& Hotchkiss, R. D. (I964). Regulation of the transformability of Pneumococcal cultures by macromolecular cell products. Proc. natn. Acad. Sci. U.S.A. 5I, 480.

Toennies, G., Bakay, B. \& Shockman, G. D. (1955). Bacterial composition and growth phase. J. biol. Chem. 234, 3269.

Weidel, W., Frank, H. \& Martin, H. H. (I960). The rigid layer of the cell wall of Escherichia coli strain B. J. gen. Microbiol. 22, 158.

Whitney, J. G. \& Grula, E. A. (1964). Incorporation of D-serine into the cell wall mucopeptide of Micrococcus lysodeikticus. Biochem. biophys. Res. Comm. 14, 375.

Young, F. E. (1965). Variation in the chemical composition of the cell walls of Bacillus subtilis during growth in different media. Nature, Lond. 207 , 104.

YounG, F. E. (1966). Autolytic enzyme associated with cell walls of Bacillus subtilis. J. biol. Chem. 241, 3462 .

Young, F. E. (1967). Competence in Bacillus subtilis transformation system. Nature, Lond. $213,773$.

Young, F. E., SpIzIzen, J. \& CRAWford, I. P. (I963). Biochemical aspects of competence in the Bacillus subtilis transformation system. I. Chemical composition of cell walls. J. biol. Chem. 238, 3119.

\section{EXPLANATION OF PLATES}

\section{Plate I}

Fig. I. Section of normal Bacillus subtilis $\mathrm{I} 68$ fixed after competence incubation followed by $3 \mathrm{hr}$ additional incubation in SL2 medium. $\times 93,000$.

Fig. 2. Section of chloramphenicol (CAP)-treated Bacillus subtilis I68 fixed after competence incubation followed by a $3 \mathrm{hr}$ treatment in SL 2 medium + CAP I $5 \mu \mathrm{g} . / \mathrm{ml} . \times 93,000$.

\section{Plate 2}

Figs. 3, 4, 5. Sections of organisms from CAP-preincubated bacteria.

Fig. 3. Organisms from a population which had been treated with lysozyme $200 \mu \mathrm{g}$. $/ \mathrm{ml}$. for $20 \mathrm{~min}$. and which contained $29 \%$ intermediate forms (see Table 8 ). $\times 19,000$.

Figs. 4 and 5. Spherical forms from a population which had been treated with lysozyme $200 \mu \mathrm{g} . / \mathrm{ml}$. for $30 \mathrm{~min}$. and which contained $23 \%$ intermediate forms. Thin remnants of cell wall cover a large proportion of the surface of the spheres. The strings of small bodies clinging to the cell surface (fig. 5) are probably residues of expelled mesosomes. $\times 46,500$. (See Ryter \& Landman, 1967; Fitz-James, 1967.)

Fig. 6. Typical organism from the same suspension as figs. 4 and 5 , taken after 80 min. of lysozyme treatment. No wall residues are visible in this protoplast. At the time of fixation, $5 \%$ of the population still behaved as intermediate forms. $\times 51,000$. 